\title{
Role of heat-shock proteins and cobalamine in maintaining methionine synthase activity
}

\author{
Michał Grabowski ${ }^{1}$, Rafał Banasiuk ${ }^{2}$, Alicja Węgrzyn ${ }^{3}$, Barbara Kędzierska ${ }^{4}$, Jan Lica ${ }^{1}$, \\ Zyta Banecka-Majkutewicz ${ }^{5}$ and Bogdan Banecki
}

'Department of Molecular and Cellular Biology; ${ }^{2}$ Department of Biotechnology, Intercollegiate Faculty of Biotechnology University of Gdańsk and Medical University of Gdańsk, Poland; ${ }^{3}$ Department of Microbiology, University of Szczecin, Szczecin, Poland; ${ }^{4}$ Department of Molecular Biology University of Gdańsk, Poland; 5 Department of Neurology, Medical University of Gdańsk, Poland

\begin{abstract}
Atheromatous plaque is one of the most common cardiovascular-related diseases. Reports show a connection between its development and the levels of homocysteine. In pathological states high levels of homocysteine in the organism can be caused by the malfunction of the methionine synthase pathway. Bacterial methionine synthase (MetH) is a homologue of the human methionine syntase (MS). In this study we aimed to investigate the functional relations between MetH and its cofactor - cobalamine - under stress conditions. We have demonstrated that heat shock proteins (Hsp 70/100 system or HtpG) can protect MetH activity under stress conditions. Moreover, in the presence of cobalamine they can restore the activity of partially denatured methionine synthase.
\end{abstract}

Key words: methionine syntase (MetH), cobalamine, HSP, HtpG, Hsp 70/100, vitamin B12

Received: 15 November, 2012; revised: 01 December, 2012; accepted: 11 December, 2012; available on-line: 18 December, 2012

\section{INTRODUCTION}

Atherosclerotic plaque is the main cause of cardiovascular related diseases. Endothelial dysfunction leads to the development of the atheromatous plaque. Reports have shown a connection between endothelial dysfunction and an elevated level of homocysteine (Lentz et al., 1996; Quere et al., 1997; Bellamy et al., 1998; Chambers et al., 1998; Kanani et al., 1999; Ungvari et al.,1999; Eberhardt et al., 2000; Lentz et al., 2000; Dayal et al., 2001; Hofmann et al. 2001; Austin et al. 2004; McCully 2005; Lentz 2005).

Homocysteine is an endogenous amino acid, not occurring in proteins, that takes part in the methylation process (Finkelstein, Martin, 1986). Even a small increase in the homocysteine level can be a significant risk factor for cardiovascular diseases (Sawuła et al.2008). During the metabolic cycle methionine is transformed to $\mathrm{S}$-adenosine methionine and used as a methyl group donor. After the transfer of the SAM methyl group S-adenosine homocysteine is formed from which homocysteine is released. In the next step homocysteine is remethylated to methionine by methionine synthase (Lentz 2005). Methionine synthase is one of the main enzymes of the folate and homocysteine metabolism. Human methionine synthase (MS) shows high homology to the bacterial methionine synthase (MetH) (Guenther et al., 1999). Activity of this protein is cobalamine-dependent (Amaratunga et al., 1995; Muld et al., 2001). MS catalyses the transfer of the $\mathrm{CH}_{3}-\mathrm{H}_{4}$ folate methyl onto homocysteine. In this reaction methionine and a biologically active form of folic acid $-\mathrm{H}_{4}$ folate - is formed (Finkelstein \& Martin, 1986; Rosenblatt \& Fenton, 2001). Vitamin deficiency, mutations and stress conditions are the main cause of dysfunction of the mentioned enzymes (Chanarin et al., 1992). Disorders in the homocysteine metabolic cycle lead to homocysteine accumulation which is a significant risk factor for cardiovascular-related diseases (Wilcken \& Wilcken 1976; Sawuła et al., 2009). Additionally, methionine synthase disorders lead to a decrease in folate availability that disrupts cell homeostasis. Stress conditions occurring in atheromatous plaque regions lead to the surplus of heat shock proteins ( $\mathrm{Xu}, 2002)$.

Heat shock proteins are a class of proteins encoded by highly conserved DNA regions. This class is divided into families based on the molecular weight of proteins. Heat shock proteins are produced either constitutively or are induced by environmental factors (Georgopoulos \& Welch 1993; Xu, 2002). They protect cells from adverse environmental factors, aid protein refolding and synthesis (Hartl, 1996). Studies have shown an increase in HSPs synthesis in atheromatous plaque rich regions (Berberian, 1990; Xu, 2002). High concentration of HSPs is supposed to reduce the stress i.e. oxidation stress (Madrigal-Matute et al., 2010) in the plaque region and to inhibit plaque expansion.

The aim of this study was to determine the role of heat shock proteins and cobalamine in maintaining the activity of Escherichia coli methionine synthase (MetH). It was demonstrated that the bacterial enzyme may be a proper model for studies on the functions of its human homologue, while possessing all advantages of the prokaryotic experimental system (Jakóbkiewicz-Banecka et al., 2005).

\section{MATERIALS AND METHODS}

Overexpression and purification of MetH. E. coli $\mathrm{K}$ - 12 XL1-Blue strain containing the pCWG-02 plasmid carrying the metH gene was inoculated into

e-mail: Bogdan Banecki e-mail: Banecki@biotech.ug.edu.pl; Zyta Banecka-Majkutewicz e-mail: zytabm@gumed.edu.pl

Abbreviations: HSP, heat shock protein; MetH, methionine syntase; SAM, S-adenosyl methionine. 
LB medium supplemented with $5 \mu \mathrm{M}$ cobalamine and ampicillin $(100 \mu \mathrm{g} / \mathrm{mL})$. The culture was carried at $37^{\circ} \mathrm{C}$ with mechanical shaking. After reaching $\mathrm{OD}_{595}=0.7$ overproduction was induced by addition of $0.5 \mathrm{M}$ IPTG. Four hours after induction the culture was centrifuged $\left(4600 \times g, 4^{\circ} \mathrm{C}, 15 \mathrm{~min}\right)$. The sediment was suspended in $50 \mathrm{mM}$ phosphate buffer $(\mathrm{pH}=7.2)$. The bacteria were lysed in a French Press. The obtained lysate was centrifuged $\left(78000 \times g, 4^{\circ} \mathrm{C}\right.$, $40 \mathrm{~min}$ ) and the resulting supernatant was applied onto a chromatographic column containing a DEAE bed $(20 \mathrm{~mL})$. The column was pre-equilibrated with $50 \mathrm{mM}$ phosphate buffer $(\mathrm{pH}=7.2)$. A linear gradient from 50 to $500 \mathrm{mM}$ phosphate buffer was used for the elution of the protein. The obtained fractions were examined using SDS/PAGE gel electrophoresis. Fractions containing the $\mathrm{MetH}$ protein were combined and dialyzed against $50 \mathrm{mM}$ phosphate buffer $(\mathrm{pH}=7.2)$. Next the sample was transferred onto a chromatographic column containing a Sorce-Q bed $(16 \mathrm{~mL})$ equilibrated with $50 \mathrm{mM}$ phosphate buffer $(\mathrm{pH}=7.2)$. The column was washed with $50 \mathrm{mM}$ phosphate buffer $(\mathrm{pH}=7.2)$ and $118 \mathrm{mM}$ phosphate buffer $(\mathrm{pH}=7.2)$. A linear gradient from 118 to 320 $\mathrm{mM}$ phosphate buffer $(\mathrm{pH}=7.2)$ was used for the elution of the protein. The collected fractions were examined using SDS/PAGE. Fractions containing pure enzyme were dialyzed against $50 \mathrm{mM}$ phosphate buffer $(\mathrm{pH}=7.2)$ after which they were frozen in liquid nitrogen and stored at $-70^{\circ} \mathrm{C}$.

Overexpression and purification of heat shock proteins. DnaK, GrpE, DnaJ, ClpB and HtpG were overproduced and purified in accordance with the previously published methods (Banecki \& Żylicz, 1996; Zylicz et al., 1987; Spence et al., 1989; Woo et al., 1992; Wawrzynów et al., 1995).

MetH activity test. The MetH activity test was performed in accordance with the methionine synthase test developed by Drummond (1995). This test measures the amount of $\mathrm{H} 4$ foliate in the $\mathrm{CH}^{+}=\mathrm{H}_{4}$ foliate form that is formed in the last step of the test. Before conducting the test all solutions were degassed. The test solution contained $100 \mathrm{mM}$ phosphate buffer $(\mathrm{pH}=7.2), 19 \mu \mathrm{M}$ SAM, $500 \mu \mathrm{M}$ homocysteine, 25 mM DTT, cobalamine (different concentrations - 10, 20, 50, $100 \mu \mathrm{M})$ and $0.375 \mu \mathrm{M} \mathrm{MetH}$. The solution was incubated for exactly 5 minutes at $37^{\circ} \mathrm{C}$. After the incubation $250 \mu \mathrm{M}(6-\mathrm{R}, \mathrm{S})-\mathrm{CH} 3-\mathrm{H} 4$ foliate was added. The volume of the reaction mixture was equal to 800 $\mu \mathrm{L}$. The reaction was carried out for 15 minutes at $37^{\circ} \mathrm{C}$ and then, after the addition of $200 \mu \mathrm{L}$ of the mixture of hydrochloric acid in acetic acid, the temperature was raised to $80^{\circ} \mathrm{C}$ and the reaction was continued for another 10 minutes. The aim of this was to convert $\mathrm{H} 4$ foliate into $\mathrm{CH}^{+}=\mathrm{H}_{4}$ foliate. MetH activity was determined based on the absorbance of $\mathrm{CH}^{+}=\mathrm{H}_{4}$ foliate at $350 \mathrm{~nm}\left(\varepsilon_{350} 26000 \mathrm{M}^{-1} \mathrm{~cm}^{-1}\right)$.

Thermal denaturation of MetH. $0.375 \mu \mathrm{M}$ MetH was pre-incubated in the presence of $100 \mathrm{mM}$ phosphate buffer $(\mathrm{pH}=7.2), 50 \mathrm{mM} \mathrm{NaCl}, 20 \mathrm{mM} \mathrm{KCl}$ and 20 $\mathrm{mM} \mathrm{MgCl} 2$ for 15 minutes in temperatures varying from 37 to $59^{\circ} \mathrm{C}$. After the incubation the sample was cooled down to room temperature and subjected to the MetH activity test.

MetH size exclusion analysis. The separation was performed using a Perkin-Elmer series 200 HPLC system equipped with a GE Healthcare Life Sciences "Superose 6, 10/300 GL column (mobile phase: $50 \mathrm{mM}$ Tris/ $\mathrm{HCl}(\mathrm{pH}=8.0), 100 \mathrm{mM} \mathrm{NaCl}$; flow $0.3 \mathrm{~mL} / \mathrm{min}$; sam- ple injection: $25 \mu \mathrm{L}$ ) The detection was carried out on a Perkin-Elmer Series 200 UV-VIS detector at $210 \mathrm{~nm}$. The analyzed samples were pre-incubated for 15 minutes at $50^{\circ} \mathrm{C}$ either with or without the addition of $50 \mu \mathrm{M}$ cobalamine.

MetH protection by HSP. $0.375 \mu \mathrm{M}$ MetH was pre-incubated in $100 \mathrm{mM}$ phosphate buffer $(\mathrm{pH}=7.2)$, $50 \mathrm{mM} \mathrm{NaCl}, 20 \mathrm{mM} \mathrm{KCl}$ and $20 \mathrm{mM} \mathrm{MgCl}_{2}$ in the presence of DnaK, DnaJ, GrpE, ClpB(Hsp 70/100 system) and $5 \mathrm{mM}$ ATP or HtpG and $5 \mathrm{mM}$ ATP. The concentration of heat shock protein was $3.7 \mu \mathrm{M}, 1.4 \mu \mathrm{M}$, $0.36 \mu \mathrm{M}, 1.5 \mu \mathrm{M}$ and $3 \mu \mathrm{M}$, respectively. Additionally, a variation of this test was performed with the addition of $50 \mu \mathrm{M}$ cobalamine. The incubation was carried out for 15 minutes at $50^{\circ} \mathrm{C}$. Finally the samples were subjected to the MetH activity test.

Renaturation of thermally inactivated MetH by the Hsp 70/100 system. $0.375 \mu \mathrm{M}$ MetH underwent thermal inactivation through a 15 minute incubation at $50^{\circ} \mathrm{C}$ in the presence of $100 \mathrm{mM}$ phosphate buffer $(\mathrm{pH}=7.2), 50 \mathrm{mM} \mathrm{NaCl}, 20 \mathrm{mM} \mathrm{KCl}$ and $20 \mathrm{mM}$ $\mathrm{MgCl}_{2}$. After incubation the enzyme was renatured in the presence of Hsp 70/100 or HtpG. Additionally, a variation of this test was performed with the addition of 50 $\mu \mathrm{M}$ cobalamine to the denatured protein. Renaturation was carried out for 45 minutes at $20^{\circ} \mathrm{C}$. Finally, the sample was subjected to the MetH activity test.

\section{RESULTS}

\section{Effect of cobalamine concentration on MetH activity.}

The effect of HSPs on the enzyme stability was studied at low and saturated cobalamine concentration. We have found that $\mathrm{MetH}$ activity strongly depends on the presence of its cofactor — cobalamine. Additionally, binding of the cofactor can stabilize the structure and stability of the enzyme. Cobalamine, at concentrations up to $40 \mu \mathrm{M}$, increases Meth activity. However, at higher concentrations the enzyme becomes saturated with the cofactor. The results of the experiment are presented in Fig. 1.

\section{MetH thermal denaturation}

The test was performed to find an optimum inactivation temperature for the analysis with the use of heat shock proteins (Fig. 2). The obtained thermal inactivation curve has shown a temperature-dependent gradual loss of activity by MetH. The temperature

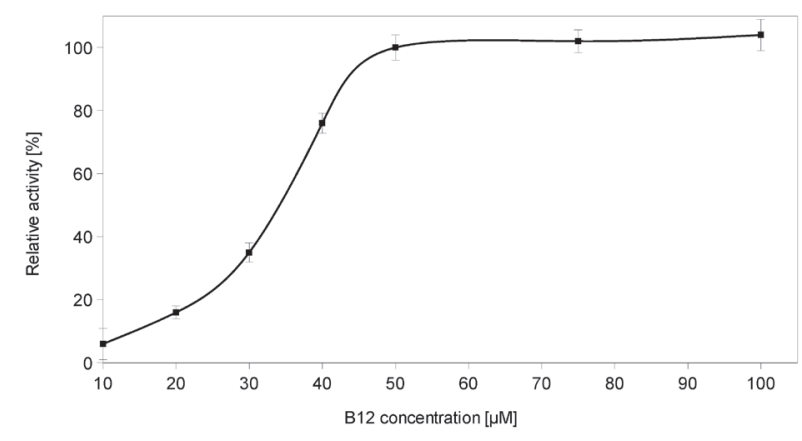

Figure 1. Kinetics of MetH activity in increasing concentration of cobalamine.

The result obtained with $50 \mu \mathrm{M}$ cobalamine was assumed as $100 \%$ of MetH activity. Data points are averages of three independent experiments. The error bars show standard deviation (S.D.). 


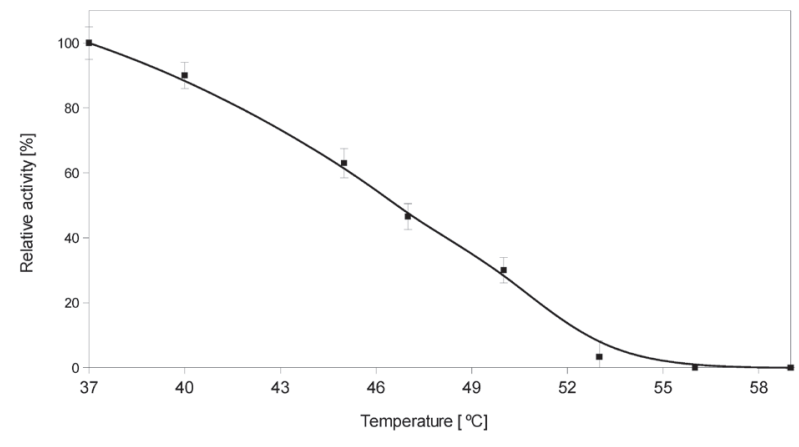

Figure 2. Kinetics of MetH thermal inactivation.

Data points are averages of three independent experiments. The error bars show standard deviation (S.D.).

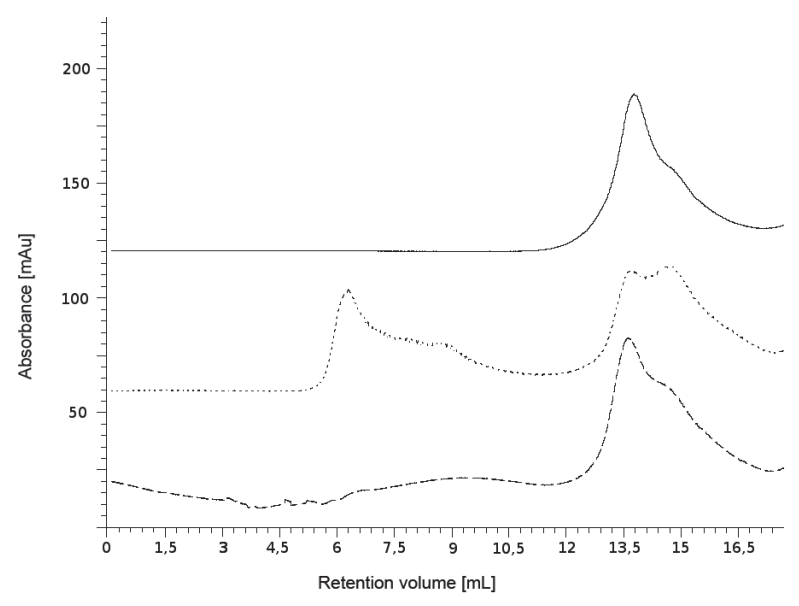

Figure 3. Size exclusion chromatography of MetH.

Experiment was performed on a Superosa 6 column with UV detection at $210 \mathrm{~nm}$. MetH was incubated at $50^{\circ} \mathrm{C}$ with or without

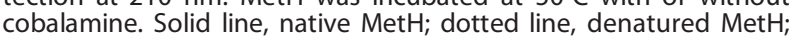
dashed line, MetH denatured in the presence of cobalamine.

of $50^{\circ} \mathrm{C}$ was chosen as optimal for further analyses. At this temperature the enzyme is partially denatured, however can still be renatured in the presence of HSPs. Size exclusion chromatography shows that at this temperature MetH starts to form aggregates (Fig. 3). Aggregation can be inhibited in the presence of cobalamine.

\section{Protection against thermal deactivation of MetH}

The reported local overproduction of HSPs in the atheromatous plaque regions suggests their important role in maintaining the functionality of the metabolic pathways including the homocysteine transformation pathway. To determine the role of heat shock proteins in $\mathrm{MetH}$ protection two tests were performed - the influence of HSPs on the denaturation process and the effect of HSPs on restoring the activity of denatured MetH. The results of the thermal deactivation tests are presented in Fig. 4. HSPs efficiently protect $\mathrm{MetH}$ against thermal inactivation. In the presence of Hsp70/100 and HtpG $70 \%$ and $59 \%$ of the activity was preserved, respectively. When cobalamine was present, up to $92 \%$ of the enzyme activity was preserved. These results prove that the Hsp 70/100 system and HtpG protect MetH from inactivation under stress conditions.

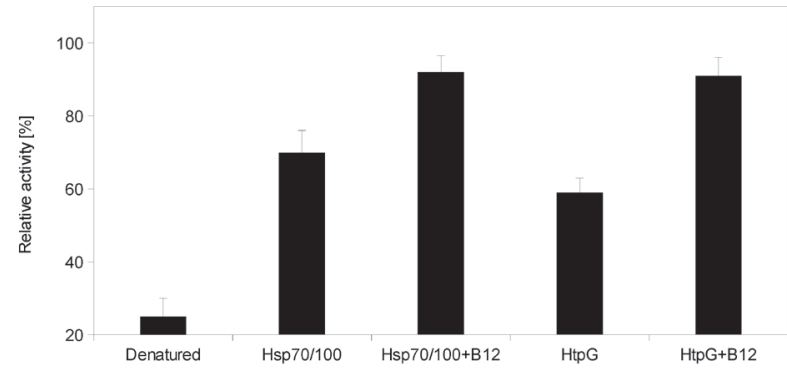

Figure 4. Protection of MetH from thermal inactivation by HSPs. Test was performed at $50^{\circ} \mathrm{C}$. The concentrations of $\mathrm{Hsp} 70 / 100$ and HtpG were as follows: Dnak 3.7 $\mu \mathrm{M}$, DnaJ $1.4 \mu \mathrm{M}$, GrpE $0.36 \mu \mathrm{M}$, ClpB $1.5 \mu \mathrm{M}$, HtpG $3 \mu \mathrm{M}$. Cobalamine concentration was $50 \mu \mathrm{M}$. Data points are averages of three independent experiments. The error bars show standard deviation (S.D.).

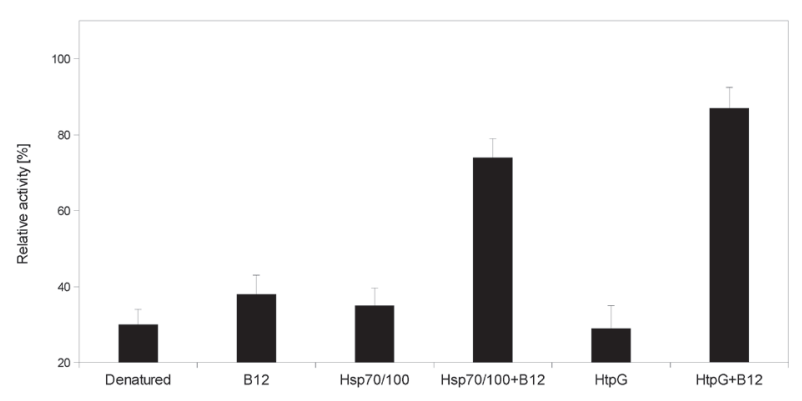

Figure 5. Renaturation of thermally inactivated MetH by Hsps. Test was performed after thermal inactivation of MetH and renaturation in the presence of selected proteins. The concentrations of Hsp70/100 and HtpG were as follows: Dnak $3.71 \mu \mathrm{M}$, DnaJ 1.41 $\mu \mathrm{M}$, GrpE $0.361 \mu \mathrm{M}$, ClpB $1.51 \mu \mathrm{M}$, HtpG $3 \mu \mathrm{M}$. Cobalamine concentration was $50 \mu \mathrm{M}$.

\section{Renaturation of thermally deactivated MetH}

The aim of this experiment was to determine the mechanisms involved in MetH protection, activity restoration and cofactor binding (Fig. 5). These mechanisms could play a key role in maintaining homeostasis in the atheromatous plaque region. Neither cobalamine nor HSPs alone could reactivate partially denatured enzyme. However renaturation in the presence of the Hsp $70 / 100$ system and an excess of cobalamine has been efficient and $74 \%$ of the enzyme activity was restored. Similar results were obtained in the presence of HtpG. In this case even $87 \%$ of the initial activity was restored. Because the Hsp 70/100 system has higher disaggregation capacity, these results suggest that HtpG assists also in cobalamine binding to the active site.

\section{DISCUSSION}

Homocysteine is one of the main risk factors of ischemic stroke and cardiovascular diseases. Disorders in the metabolism of homocysteine and its overall high concentration are connected with the formation of the atheromatous plaque and with stress condition conditions in the blood vessels. Increased levels of homocysteine are usually caused by its metabolic pathway dysfunction or diet. Activity of $\mathrm{MetH}$, one of the main enzymes of the metabolic pathway of homocysteine, depends on its 
cofactor - cobalamine bound to the active site. Upon stress conditions MetH aggregates, the cofactor dissociates and the activity of the enzyme decreases. The presented study may help to broaden the understanding of the etiology of cardiovascular diseases. We have shown that elevated concentration of cobalamine, can maintain enzyme activity. This result may explain why B - group vitamin diet supplementation is one of the elements in the therapy to prevent stroke (Toole et al., 2004).

However, in the atheromatous plaque region the Hsp family proteins are overexpressed and this results in slowing down the process of atherosclerosis development. Under stress conditions the heat shock proteins preserve the native structure of the enzyme and prevent the dissociation of the cobalamine cofactor. This may play a key role in maintaining the activity of methionine synthase ensuring the functionality of the homocysteine and folic acid metabolic pathways. HSPs not only protect MetH from inactivation but also restore its activity after inactivation. The role of the Hsp 70/100 system in enzymatic activity recovery following stress conditions is limited to structure refolding. We speculate that Hsp 70/100 restores MetH structure but does not restore enzyme activity. Only in the presence of cobalamine a significant increase in activity is observed. This proves that the MetH molecule has a natural ability to bind the cofactor to the active site and this reaction is limited by the concentration of cobalamine.

HtpG is a bacterial Hsp 90 protein with established activity in maintaining homeostasis. As the representative of the Hsp 90 family, HtpG interacts with many substrates and is involved in protein protection and synthesis. The results of our experiments show that HtpG not only protects MetH from thermal inactivation but also restores its activity. It is even more efficient than the Hsp70/100 system. Probably, when cobalamine is present in excess, HtpG inflicts conformational changes in the MetH molecule that lead to rebinding of the cofactor. In the case of minor structural changes of MetH, the activity of HtpG may play an important role in maintaining MetH activity. However under high stress conditions the activity of HtpG alone may not by sufficient.

Probably in case of severe structural damage, the Hsp 70/100 system and HtpG cooperate as a complete system maintaining and restoring MetH activity (Genest et al., 2011). Taking into account the number of substrates that can interact with Hsp70/100 and HtpG its activity is not specific towards MetH. Probably under stress conditions both systems are responsible for the maintenance of $\mathrm{MetH}$ activity. This activity leads to a local decrease in homocysteine level. Increased homocysteine concentration induces oxidative stress in the cell. Thus decreasing the level of homocysteine can contribute to alleviating stress conditions and reducing the effects of development of the plaque.

\section{REFERENCES}

Amaratunga M, Fluhr K, Jarrett J, Drennan K, Ludwig M, Matthews R, Scholten J (1996) A synthetic module for the metH gene permits facile mutagenesis of the cobalamin-binding region of Escherichia coli methionine synthase: initial characterization of seven mutant proteins. Biochemistry 35: 2453-2463.

Austin RC, Lentz SR, Werstuck GH (2004) Role of hyperhomocysteinemia in endothelial dysfunction and atherothrombotic disease. Cell Death Diff 11: 56-64.
Banecki B, Zylicz M (1996) Real time kinetics of the DnaK/DnaJ/ GrpE molecular chaperone machine action. J Biol Chem 271: 61376143.

Bellamy MF, Mcdowell IFW, Ramsey MW, Brownlee M, Bones C, Newcombe RG, Lewis MJ (1998) Hyperhomocysteinemia after an oral methionine load acutely impairs endothelial function in healthy adults. Circulation 98: 1848-1852.

Berberian P, Myers W, Tytell M, Challa V, Bond M (1990) Immunohistochemical localization of heat shock protein-70 in normal-appearing and atherosclerotic specimens of human arteries. Am J Pathol 136: $71-80$.

Chambers JC, McGregor A, Jean-Marie J, Kooner JS (1998) Acute hyperhomocysteinemia and endothelial dysfunction. Lancet 351: 36-7.

Chanarin I, Deacon R, Lumb M, Perry J (1992) Cobalamin-folate: Recent developments. J Clin Path 45: 277-283.

Dayal S, Bottiglieri T, Arning E, Maeda N, Malinow MR, Sigmund CD, Heistad DD, Faraci FM, Lentz SR (2001) Endothelial dysfunction and elevation of S-adenosylhomocysteine in cystathionine $\beta$-synthasedeficient mice. Cir Res 88: 1203-1209.

Drummond JT, Jarrett J, González J C, Huang S, Matthews RG (1995) Characterization of nonradioactive assays for cobalamin-dependent and cobalaminindependent methionine synthase enzymes. Anal Biochem 228: 323-329.

Eberhardt RT, Forgione MA, Cap A, Leopold JA, Rudd MA, Tolliet M, Heyrick S, Stark R, Klings ES, Moldovan NI, Yaghoubi M, Goldschmidt-Clermont PJ, Farber HW, Cohen R, Loscalzo J (2000) Endothelial dysfunction in a murine model of mild hyperhomocyst(e) inemia. I Clin Invest 106: 483-491.

Finkelstein JD, Martin JJ (1986) Methionine metabolism in mammals. Adaptation to methionine excess. J Biol Chem 261: 1582-1587.

Genest O, Hoskins J, Camberg J, Doyle A, Wickner S (2011) Heat shock protein 90 from Escherichia coli collaborates with the DnaK chaperone system in client protein remodeling. Proc Natl Acad Sci USA 108: 8206-8211.

Georgopoulos C, Welch WJ (1993) Role of the major heat shock proteins as molecular chaperones. Annu Rev Cell Biol 9: 601-634.

Guenther BD, Sheppard CA, Tran P, Rozen R, Matthews RG, Ludwig ML (1999) The structure and properties of methylenetetrahydrofolate reductase from Escherichia coli suggest how folate ameliorates human hyperhomocysteinemia. Nat Struct Biol 6: 359-365.

Hartl FU (1996) Molecular chaperones in cellular protein folding. $\mathrm{Na}$ ture 381: 571-580.

Hofmann MA, Lalla E, Lu Y, Gleason MR, Wolf BM, Tanji N, Ferran LJJr, Kohl B, Rao V, Kisiel W, Stern DM, Schmidt AM (2001) Hyperhomocysteinemia enhances vascular inflammation and accelerates atherosclerosis in a murine model. I Clin Invest 107: 675-683.

Jakóbkiewicz-Banecka J, Kloska A, Stepnowska M, Banecki B, Węgrzyn A, Wegrzyn G (2005) A bacterial model for studying effects of human mutations in vivo: Escherichia coli strains mimicking a common polymorphism in the human MTHFR gene. Mutation Res 578: 175186.

Kanani PM, Sinkey CA, Browning RL, Allaman M, Knapp HR, Haynes WG (1999) Role of oxidant stress in endothelial dysfunction produced by experimental hyperhomocyst(e)inemia in humans. Circulation 100: 1161-1168.

Lentz SR, Sobey CG, Piegors DJ, Bhopatkar MY, Faraci FM, Malinow MR, Heistad DD (1996) Vascular dysfunction in monkeys with diet-induced hyperhomocyst(e)inemia. J Clin Invest 98: 24-29.

Lentz SR, Erger RA, Dayal S, Maeda N, Malinow MR, Heistad DD, Faraci FM (2000) Folate dependence of hyperhomocysteinemia and endothelial dysfunction in cystat hionine $\beta$-synthase-deficient mice. Am J Pbysiol 278: 970-975.

Madrigal-Matute J, López-Franco J, Blanco-Colio L, Munoz-Garcia B, Ramos-Mozo P, Ortega L, Egido J, Martin-Ventura J (2010) Heat shock protein 90 inhibitors attenuate inflammatory responses in atherosclerosis. Cardiovascular Res 86: 330-337.

McCully K (2005) Hyperhomocysteinemia and arteriosclerosis: historical perspectives. Clin Chem Lab Med 43: 980-986.

Quéré I, Hillaire-Buys D, Brunschwig C, Chapal J, Janbon C, Blayac J, Petit P, Loubatières-Mariani M (1997) Effects of homocysteine on acetylcholine- and adenosine-induced vasodilatation of pancreatic vascular bed in rats. Br J Pharmacol 122: 351-357.

Rosenblatt DS, Fenton WA (2001) Inherited disorders of folate and cobalamin transport and metabolism. In The Metabolic and Molecular Basies of Inherited Disease. Scriver CR, Beaudet Al, Sly WS, Valle D, eds, pp 3897-3933. McGraw-Hill, New York.

Sawuła W, Banecka-Majkutewicz Z, Kadziński L, Jakóbkiewicz-Banecka J, Wegrzyn G, Nyka W, Banecki B (2008) Improved HPLC method for total plasma homocysteine detection and quantification. Acta Biochim Pol 55: 119-125.

Sawuła W, Banecka-Majkutewicz Z, Kadziński L, Jakóbkiewicz-Banecka J, Wegrzyn G, Nyka W, Banecki B (2009) Homocysteine level and metabolism in ischemic stroke in the population of Northern Poland. Clin Biochem 42: 442-447.

Spence J, Georgopoulos C (1989) Purification and properties of the Escherichia coli heat shock protein, HtpG. J Biol Chem 264: 4398-4403. 
Toole JF, Malinow MR, Chambless LE, Spence JD, Pettigrew LC, Howard VJ, Sides EG, Wang CH, Stampfer M (2004) Lowering homocysteine in patients with ischemic stroke to prevent recurrent stroke, myocardial infarction, and death: the Vitamin Intervention for Stroke Prevention (VISP) randomized controlled trial. J Am Med Ass 291: 565-75.

Ungvari Z, Pacher P, Rischak K, Szollar L, Koller A (1999) Dysfunction of nitric oxide mediation in isolated rat arterioles with methionine dietinduced hyperhomocysteinemia. Arterioscl Thromb Vasc Biol 19: 1899-1904.

Wawrzynów A, Banecki B, Wall D, Liberek K, Georgopoulos C, Zylicz $\mathrm{M}$ (1995) ATP hydrolysis is required for the DnaJ-dependent activa- tion of DnaK chaperone for binding to both native and denatured protein substrates. J Biol Chem 270: 19307-19311.

Wilcken DE, Wilcken B (1976) The pathogenesis of coronary artery disease. A possible role for methionine metabolism. I Clin Invest 57: 1079-1082.

Woo KM, Kim KI, Goldberg AL, Ha DB, Chung CH (1992) The heat-shock protein ClpB in Escherichia coli is a protein-activated ATPase. J Biol Chem 267: 20429-20434.

Xu Q (2002) Role of heat shock proteins in atherosclerosis. Arterioscler Thromb Vasc Biol 22: 1547-1559.

Żylicz M, Ang D, Georgopoulos C (1987) The grpE protein of Escherichia coli. Purification and properties. J Biol Chem 262: 17437-17442. 